\title{
Quality of self-management among diabetes mellitus patient
}

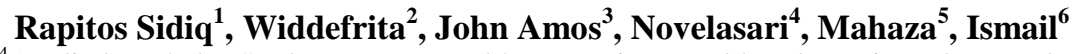 \\ ${ }^{1,2,3,4}$ Applied Bachelor Study Program Health Promotion, Health Polytecnic Padang, Indonesia \\ ${ }^{5}$ Department of Environmental, Health Health Polytecnic Padang, Indonesia \\ ${ }^{6}$ Department of Nursing, Health Polytecnic Aceh, Indonesia
}

\section{Article Info}

Article history:

Received Jul 16, 2020

Revised Nov 30, 2020

Accepted Jan 3, 2021

\section{Keywords:}

Diabetes mellitus

Diabetics

Education

Physical exercise

Self-management

\begin{abstract}
Diabetes mellitus is a chronic disease that has very high morbidity and mortality rate. This disease cannot be cured but can be controlled with good self-management. This research determined the quality of self-management of diabetics at community health centers in Padang City in 2019. This is a descriptive-analytic study with amount of samples 105 people with diabetes. Data collection was carried out from July to November 2019 at seven community health centers in Padang City, namely: Nanggalo, Lapai, Alai, Andalas, Ambacang, Kuranji and Pauh community health centers. Data were collected by interviewing and processed by the stages of coding, editing, tabulating, and transferring. Data were analyzed by bivariate and multivariate analysis (Chi-square and logistic regression) with a significant level of 0.05 $(5 \%)$. The results showed that $60 \%$ of the quality of self-management in good category. Factors that significantly affect the quality of selfmanagement are physical exercise/sports ( $\mathrm{p}$-value $=0.003$ ), education ( $\mathrm{p}$ value $=0.006)$ and regularity of taking medication ( $p$-value $=0.021)$. The quality of self-management is largely good and physical exercise greatly affects the quality of self-management of diabetes mellitus patients.
\end{abstract}

This is an open access article under the $\underline{C C B Y-S A}$ license.

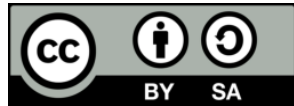

\section{Corresponding Author:}

Rapitos Sidiq

Health Promotion Study Program

Health Polytechnic Padang

Jl. Simpang Pondok Kopi, Siteba, Padang, West Sumatera, Indonesia

Email: rapitos@poltekkespadang.ac.id

\section{INTRODUCTION}

Diabetes mellitus is a non-communicable disease that has become a problem of global health today, because of the complications. The prevalence of global diabetes is more than doubled over the past three decades, with prevalence rates far exceeding projections, almost 1 in 10 adults worldwide now have diabetes, even in 2015, the percentage of adults suffering from diabetes reaches $8.5 \%$ ( 1 out of 11 adults suffer from diabetes mellitus) in the world [1,2]. In 2019 it is estimated that the global prevalence of Diabetes Mellitus is 9.3 (463 million people), increasing to $10.2 \%$ (578 million) in 2030, and 10.9\% (700 million) in 2045 [3]. This disease is the third leading cause of death in 2014 [4]. In addition to causing the highest deaths, health spending due to diabetes continues to increase throughout the world with social and financial implications [5]. Indonesia ranks seventh with diabetes in the world along with China, India, the United States, Brazil, Russia and Mexico with an estimated 10 million sufferers in 2015 [6]. Based on the latest data from the Basic Health Research (Riskesdas) 2018, in general, the prevalence of diabetes has increased significantly over the past five years lastly. In 2013, the prevalence of diabetes in adults reached $6.9 \%$, and in 2018 the figure continued to surge to $8.5 \%$ [7]. The percentage of deaths due to diabetes in Indonesia is the second-highest after Sri Lanka. In addition to diabetes mellitus, including five diseases with the highest 
burden of hospitalization in Indonesia after heart disease, stroke, and kidney disease, the government has made it a priority for the Healthy Life Movement (GERMAS) program with the main activities being to improve the implementation of early detection at the Puskesmas and compile a detection implementation guide. early in government and private agencies [8]. Riskesdas 2018 in West Sumatra Province, found the prevalence of Diabetes Mellitus based on Doctor's Diagnosis of the population of all ages is $1.6 \%$ higher than the national average of $1.5 \%$ and ranks 14 th out of 33 provinces. For the city of Padang, the number of new cases of diabetics in 2017 was 3,514 cases, while in 2018 up to May it reached 2,532 cases, from these data the districts of Padang Utara and Nanggalo were the highest areas of diabetics (Padang City e-puskesmas data, accessed on July 31, 2019) [9].

Diabetes Mellitus cannot be cured, but efforts are needed to improve the quality of life of sufferers. To improve the quality of life of diabetics it is necessary to control efforts with four main pillars, namely education, eating, exercise, medication adherence [10]. Experts refer to the term self-management or Selfmanagement of diabetics with diabetes mellitus, which is an effort that diabetics can do to formability in managing himself, cultivating lifestyles following the demands of his illness, so self-management is very important, with the existence of self-management is expected to have an impact on controlling blood sugar [11-13]. Self-management of diabetics refers to several activities namely monitoring the signs and symptoms, maintain and improve health behavior, and overcome the negative impact of the disease on the physical functioning of sufferers, emotional feelings, and interpersonal relationships [14], because the key to controlling type 2 diabetes is to change the sufferer's lifestyle in the form of self-management [15]. One very important aspect of selfmanagement is education. Education aims to reduce or maintain blood sugar stability, regulate diet and manage the disease $[16,17]$. Health education that is followed by diabetics is very important to control the disease, with education it can increase the knowledge of diabetics and increase their awareness [18, 19]. But to do Such education is not as easy as one might imagine, it needs systematic efforts, although health education is suitable for various levels of age, gender and education (17). The government has initiated various programs to improve the quality of life of people with diabetes, one of which is a chronic disease service program (PROLANIS), which includes diabetes and hypertension. The aim is to achieve optimal quality of life with the cost of effective and efficient health services [20].

The results of Sidiq's et al, research in 2018 at the Meurasi Lambaro Aceh Besar clinic basic service facility in Aceh Province, found that of 52 diabetics who participated in the PROLANIS program, 27 people or $52 \%$ had poor self-management, this had an impact on sugar instability blood, also found some diabetics who have hypoglycemia due to a strict diet by not eating so that their physical condition is weak [21]. The initial survey conducted by researchers in July 2019, at several community Health centers Padang City, found that not all DM sufferers were registered In PROLANIS actively participating in ctivities, with a variety of reasons, such as not having time because they have to work, no one takes the morning sufferers who are elderly and due to weak physical condition. Researchers also found some DM sufferers who were not actively participating in this program, came to the Puskesmas in a weak physical condition and high blood sugar. This research is a preliminary study to find out the quality of self-management in people with diabetes mellitus at the Puskesmas in Padang City in 2019.

\section{RESEARCH METHOD}

This descriptive-analytic study was conducted from July to November 2019 on seven community health centers in Padang City, namely Lapai, Ambacang, Nanggalo, Alai, Andalas, Kuranji, and Pauh community health centers. The number of samples are 105 people with Diabetes Mellitus who seek treatment at community health centers between July to November 2019. Data were collected by interview using a questionnaire that adapted from the diabetes self-management questionnaire, the summary of diabetes self-care activities (SDSCA) [22]. Which has been modified, that includes items assessing the following aspects of the diabetes regimen: Dietary Regulation, exercise, blood-glucose testing, health education , and information needs. Data was processed by coding, editing, tabulating and transferring stages. Data was processed by using a computerized system. Data was analyzed by using univariate and bivariate with chisquare and multivariate with logistic regression with a significant level of 0.05 (5\%). Univariate analysis was used to explain the characteristics of the respondents, univariate analysis was used to explain the characteristics of respondents, while bivariate analysis is used to describe the relationship between participation in PROLANIS variables and quality of self-management. Multivariate analysis was used to determine the relationship between the independent variables and the dependent variable.

Int. J. Public Health Sci. Vol. 10, No. 1, March 2021: $33-40$ 


\section{RESULTS AND DISCUSSION}

\subsection{Characteristics of respondents}

The characteristics of respondents describe in Table 1. The table shows that the majority of respondent are women. In terms of age 67.6\% aged between 56-65 years or late elderly (age division according to the Indonesian Ministry of Health (2009). Most of respondents are no work with $83.8 \%$ and 25.7 $\%$ of respondents are from Andalas Community Health Center and followed with Pauh community Health Center with amount of respondents are 23 respondents $(21.9 \%)$.

Table 1. Characteristics of respondents

\begin{tabular}{lrr}
\hline \multicolumn{1}{c}{ Characteristics } & $\mathrm{n}$ & $\%$ \\
\hline Sex & & \\
Male & 13 & 12.4 \\
Female & 92 & 87.6 \\
Age & & \\
Middle age (45-55 years) & 34 & 32.4 \\
Elderly (56-65 years) & 56 & 53.3 \\
Old(> 65 years) & 15 & 14.3 \\
Occupational status & \multicolumn{2}{c}{} \\
Work & 17 & 16.2 \\
No Work & 88 & 83.8 \\
Origin of community health centers \\
Alai & 9 & 8.6 \\
Ambacang & 14 & 13.3 \\
Andalas & 27 & 25.7 \\
Kuranji & 12 & 11.4 \\
Lapai & 5 & 4.8 \\
Nanggalo & 15 & 14.3 \\
Pauh & 23 & 21.9 \\
\hline
\end{tabular}

\subsection{Participation in PROLANIS and quality of self-management}

Aspects of self-management can be seen from the examination of blood sugar, physical exercise (sports), dietary regulation and health education as well as two supporting aspects, namely participation in PROLANIS and information needs. The categorization of these variables is based on the median value of each variable value. A comparison between these aspects with the quality of self-management can be seen in Table 2.

Table 2. Aspects and quality of self-management

\begin{tabular}{llrrrr}
\hline \multirow{2}{*}{ Self-management aspects } & & Quality of self-management & \multirow{2}{*}{ Total } & \multirow{2}{*}{ p } \\
\cline { 2 - 6 } Participation in the PROLANIS & Active & $50(68.49 \%)$ & $23(31.51 \%)$ & 73 & \multirow{2}{*}{0.007} \\
& Passive & $13(40.63 \%)$ & $19(59.38 \%)$ & 32 & \\
\hline
\end{tabular}

From Table 2, it is found that of the 73 respondents who participated in PROLANIS, most of them namely $68.49 \%$, had good self-management quality, and from 32 respondents who did not follow PROLANIS, the majority, namely $59.38 \%$, had poor self-management quality, with the significant value is $\mathrm{p}<\alpha 0.05$ ( $\mathrm{p}=0.007)$, it can be concluded that the participation of Diabetes mellitus patients in PROLANIS has a significant relation to the quality of self-management.

The aspect of participation in PROLANIS is the first factor related to self-management of diabetics, and this is consistent with various studies in Indonesia. Various studies in Indonesia have also proven that PROLANIS has a better impact on the health condition of diabetics. [23, 24]. This research has also identified the problems faced by diabetics in self-management, both those who participate in PROLANIS activities and those who do not. This study also found differences in the quality of self-management between those who followed PROLANIS and those who did not, thus diabetics needed a system for life to be organized, well managed so that living in regular conditions to maintain the stability of blood sugar levels so that the quality of life would be good [10]. The quality of self-management is inseparable from several factors that support it, such as gender, occupation, and age. For gender factors, this study has identified the majority of respondents are women (87.6\%) aged between 56-65 years who are not working. Women have a higher average quality of life value for age because it is easier to understand activities to prevent diabetes in daily life [25]. This is because women have enough time to participate in PROLANIS activities such as physical activities such as gymnastics, health education and blood sugar checking activities. Through 
programs like this, diabetics can also socialize with fellow sufferers, so they can reduce the burden of their mental illnesses because they can share information in overcoming negative effects of illness, daily selfmanagement, emotional feelings, and interpersonal relationships [14, 15, 26, 27].

In this study found two things that are also very interesting, the first is that not all diabetics who have participated in PROLANIS activities have a good self-management quality which is $31.51 \%$, It mean that some diabetics have participated in this activity but have not been able to change their lifestyle which is following the demands of diabetes self-management. For this condition, it is necessary to study deeply the factors causing this to occur, several factors that can be taken into consideration such as; perceptions of respondents about the purpose of blood sugar testing activities, emotional conditions, pain, cost and motivation of the family, including the patient's attitude towards the quality of information [28, 29]. Greatly affect the results of PROLANIS activities, especially educational activities, so it needs a strategy to overcome them [30]. In terms of the participant, fees do not have to pay because this activity is fully funded by Indonesian health insurance agency (BPJS), especially for laboratory examinations. The factor of family support is also very decisive. Family and social support are important aspects of adherence to diabetes management. Numerous studies have shown a positive and significant relationship between social support and adherence to diabetes treatment. Including social support directly affects health outcomes, health service utilization, and behavior change [31-33]. Ideally, families with members who have diabetes should have a role to play in helping diabetics [34]. This study found that most diabetics come to the facility health is not accompanied by their families, except diabetics with weak physical conditions with high blood sugar levels. Next is what about diabetics with diabetes self-management who do not follow PROLANIS. This study found $59.38 \%$ of diabetics who did not follow PROLANIS with poor self-management conditions. In this case, advocacy is needed so that diabetics can do good self-management even though they cannot join the PROLANIS.

\subsection{Aspect and quality of self-management}

Aspects of self-management can be seen from the examination of blood sugar, physical exercise (sports), dietary regulation, Medication adherence and health education as well as two supporting aspects, namely participation in PROLANIS and information needs. The categorization of these variables is based on the value of each variable value, for variabel of participation in the PROLANIS $\bar{x}=4.3$, examination of blood sugar $\bar{x}=8.11$, physical exercise (sports) $\bar{x}=6.8$, the regularity of taking medication $\bar{x}=4.00$, dietary regulation $\bar{x}=15.6$, health education $\bar{x}=3.00$, information need $\bar{x}=29.1$, the comparison of these values and their relationship with the quality of self-management can be seen in Table 3.

Table 3. Aspects and quality of self-management

\begin{tabular}{|c|c|c|c|c|c|}
\hline \multirow{2}{*}{\multicolumn{2}{|c|}{ Self-management aspects }} & \multicolumn{2}{|c|}{ Quality of self-management } & \multirow{2}{*}{ Total } & \multirow{2}{*}{$\mathrm{p}$} \\
\hline & & Good & Not good & & \\
\hline \multirow{2}{*}{ Examination of blood sugar } & Rutine & $40(70.18)$ & $17(29.82)$ & 57 & \multirow{2}{*}{0.020} \\
\hline & Not rutine & $23(47.92)$ & $25(52.8)$ & 48 & \\
\hline \multirow{2}{*}{ physical exercise (sports) } & Rutine & $44(73.33)$ & $16(26.67)$ & 60 & \multirow{2}{*}{0.01} \\
\hline & Not rutine & $19(42.22)$ & $26(57.78)$ & 45 & \\
\hline \multirow{2}{*}{ The regularity of taking medication } & Regular & $60(66.7)$ & $30(33.3)$ & 90 & \multirow{2}{*}{0.001} \\
\hline & Not reguler & $3(20)$ & $12(80)$ & 15 & \\
\hline \multirow[t]{2}{*}{ Dietary regulation } & Good & $50(63.29)$ & $29(36.71)$ & 79 & \multirow{2}{*}{0.23} \\
\hline & Not good & $13(50)$ & $13(50)$ & 26 & \\
\hline \multirow[t]{2}{*}{ Health education } & Yes & $46(70.77)$ & $19(29.32)$ & 65 & \multirow{2}{*}{0.004} \\
\hline & No & $17(42.50)$ & $23(57.50)$ & 40 & \\
\hline \multirow{2}{*}{ Information need } & High & $30(54.5)$ & $25(45.5)$ & 55 & \multirow{2}{*}{0.231} \\
\hline & Low & $33(60.1)$ & $17(39.9)$ & 50 & \\
\hline
\end{tabular}

Based on Table 2 above, it is found that there are 5 aspects of self-management that are related to the quality of self-management of diabetics, namely participation in PROLANIS ( $\mathrm{p}=0.007)$, examination of blood sugar $(\mathrm{p}=0.02)$, exercise $(\mathrm{p}=0.01)$, Regularity of taking medication $(\mathrm{p}=0.001)$, and Health Education (0.004), while the aspects of Food Regulation and Information Needs do not have a significant relationship to the quality of self-management of diabetics. Furthermore, for aspects of self-management related to the quality of self-management to multivariate analysis.

\subsection{Factor determine analysis}

Multivariate analysis is used to determine the relationship between the independent variables tothe dependent variable by using the logistic regression test. The logistic regression test results are presented in 
the following Table 4, which explains the extent to which the strength of each aspect or variable has a relationship to self-management of people with diabetes mellitus .

From the six aspects of self-management, the aspects of blood sugar testing, dietary regulation, and information needs have a p-value $>0.25$, so that these three aspects are not feasible for multivariate analysis, only physical exercise/sports, regularity of taking medication and education can be done by multivariate analysis, because they have a $\mathrm{p}$-value $<0.25$. three aspects of self-management, show the results as follows.

Based on the Table 5 above, it is found that results of tests on the three aspects of self-management, the aspects of physical exercise/sports and education greatly affect the quality of self-management of diabetes mellitus patients rather than regularity of taking medication, although basically, all three aspects have a p-value $<0.05$, it mean each of these aspects has a significant partial effect on the self-management of diabetics.

Table 4. The logistic regression test results

\begin{tabular}{lccc}
\hline \multicolumn{1}{c}{ Self-management aspects } & OR & $95 \%$ CI & $\mathrm{p}$ \\
\hline Blood-glucose testing & 1.05 & $0.84-1.30$ & 0.675 \\
Physical exercise/sports & 1.12 & $1.05-1.36$ & 0.006 \\
Dietary regulation & 0.10 & $0.92-1.83$ & 0.943 \\
The regularity of taking medication & 2.04 & $1.10-3.77$ & 0.024 \\
Education & 1.66 & $1.15-2.39$ & 0.007 \\
Information needs & 0.98 & $0.91-1.06$ & 0.642 \\
\hline
\end{tabular}

Table 5. The logistic regression test results

\begin{tabular}{lccc}
\hline \multicolumn{1}{c}{ Self-management aspects } & OR & $95 \%$ CI & $\mathrm{p}$ \\
\hline Physical exercise/sports & 1.12 & $1.064-1.35$ & 0.003 \\
Education & 1.66 & $1.156-2.35$ & 0.006 \\
The regularity of taking medication & 2.04 & $1.113-3.75$ & 0.021 \\
\hline
\end{tabular}

Subsequent studies on the contribution of aspects of self-management to the quality of selfmanagement of diabetics found that aspects of blood sugar testing, dietary regulation, and information requirements did not meet the requirements to be modeled as aspects that affect the quality of selfmanagement, but instead, physical aspects of exercise/exercise, education and regularity of taking medication have a significant partial effect on the self-management of diabetics. Physical exercise/exercise routinely affects the quality of self-management of diabetics, this will certainly have a positive impact on blood sugar control [35]. Research shows that there is a relationship between sports behavior with blood sugar levels of people with diabetes mellitus, so physical activity and exercise are recommended as part of glycemic control management and overall health [36, 37]. The effects of physical activity on controlling glucose in the blood will vary depending on how long the activity takes, because at the time of physical activity or exercise the body cells will increase their sensitivity to the hormone insulin, the cardiovascular system and breathing constantly adjusts to the workload of the exercise to ensure that blood rich in glucose and oxygen $(\mathrm{O} 2)$ reaches the muscles that are working at the required speed. Increased brain motor activity centers and skeletal muscle afferents (tension) and metabolic muscles (for example, $\mathrm{H}+, \mathrm{K}+$, and local ischemia) stimulate sympathetic nervous system activity and cause increased catecholamine circulation acting on adrenoceptors in skeletal muscle cells and cells and consequently vasodilation in healthy individuals [36].

This study also found the impact of educational factors on the quality of diabetes management selfmanagement. Many other studies have found a positive impact of education on the self-management of diabetics which in turn has an impact on maintaining blood sugar stability, regulating diet and managing disease [16, 17, 19]. Infertility in drinking is also a factor that greatly contributes to the quality of management diabetics themselves. A number of factors can influence the regularity of taking this medication such as education level, duration of diabetes, and knowledge about DM and its treatment and health education including adherence counseling to create awareness of DM and its treatment [38-40].

\subsection{Difficulties in self-management}

To get an overview of the difficulties in self-management experienced by respondents so far, the frequency distribution data is obtained based on the categories of answer choices and scores: Strongly Disagree $=5$, Disagree $=4$, Neutral $=3$, Agree $=2$, Strongly Agree $=1$, the results can be seen from Table 5 .

Based on Table 6, it can be seen that the majority of respondents did not experience difficulties in the aspects of self-management (taking medication, eating patterns, checking blood sugar, physical exercise or sports, managing emotions and accessing information), this is because of most of the respondents joined in 
the proteins (69.5\%). In PROLANIS activities in addition to physical activities such as gymnastics, health counseling there is also blood sugar checking activities every month. But for respondents who did not join the PROLANIS had problems or difficulties. Of all the aspects of self-management of diabetes mellitus patients, emotional/stress management is a very interesting aspect. As a percentage of the number of respondents who disagree have difficulty in managing emotions/stress higher than those who agree that is more than $50 \%$ (26.7\% strongly disagree and $24.8 \%$ agree), but there are $18.1 \%$ who declare neutral, more than $30 \%$ admit the difficulty in managing emotions/stress so that their blood sugar levels rise.

Table 6. Overview of aspects of self management

\begin{tabular}{|c|c|c|c|c|c|c|}
\hline Aspects of self-management & $\begin{array}{l}\text { Strongly } \\
\text { disagree }\end{array}$ & Disagree & Neutral & Agree & $\begin{array}{l}\text { Strongly } \\
\text { agree }\end{array}$ & Total \\
\hline Difficulty of taking medication & $34(3.4)$ & $32(30.5)$ & $10(9.5)$ & $24(22.9)$ & $5(4.8)$ & 105 \\
\hline Difficulty of regulating diet & $26(24.8)$ & $31(29.5)$ & $23(21.9)$ & $19(18.1)$ & $6(5.7)$ & 105 \\
\hline Difficulty of checking blood sugar regularly & $50(47.6)$ & $25(23.8)$ & $15(14.3)$ & $10(9.3)$ & $5(4.8)$ & 105 \\
\hline $\begin{array}{l}\text { Difficulty in carrying out regular physical } \\
\text { exercise or sports }\end{array}$ & $26(24.8)$ & $35(33.3)$ & $18(17.1)$ & $16(15.2)$ & $10(9.5)$ & 105 \\
\hline Difficulty of managing emotions/stress & $28(26.7)$ & $26(24.8)$ & $19(18.1)$ & $22(21)$ & $10(9.5)$ & 105 \\
\hline Difficulty in getting information & $36(34.3)$ & $24(22.9)$ & $19(18.1)$ & $14(13.3)$ & $12(11.4)$ & 105 \\
\hline
\end{tabular}

This research identifies the difficulties in this aspect of self-management, and most respondents did not experience difficulties, but from all aspects of self-management, it is very interesting to study more deeply, namely the management of emotions and stress, as described previously in percentage of the number of respondents who have difficulty of managing emotions/stress more than $30 \%$, this has an impact on the stability of blood sugar levels. In an unstable emotional state or stress the blood sugar will increase due to the influence of hormones [41]. Not only calorie intake, body mass index, but stress and family income are associated with increased levels of HbA1c. so diabetics must pay attention to these biopsychosocial factors and calorie intake to control blood sugar [42, 43]. This study identifies that it turns out a number of problems that cause these diabetics to experience emotional distress/stress are economic and family problems. This is precisely experienced by people with diabelts mellitus who are not involved in PROLANIS activities, do not have fixed income and early elderly. Stress and diabetes are like vicious circles [44]. Although there are also studies that find no direct correlation between stress and an increase in blood sugar [45]. So, a stress management intervention is needed to help reduce stress and increase self-efficacy, social support [46].

\section{CONCLUSION}

The quality of self-management of diabetes patients at the community health centers in Padang is in a good category. A number of factors that related to the quality of self-management are physical/sports training, education, and regular medication. There is a difference in the quality of self-management between people with diabetes mellitus who participate in PROLANIS activities and those who do not. Management of stress or emotions is an interesting factor to be followed up especially in diabetics who do not participate in PROLANIS activities.

\section{ACKNOWLEDGEMENTS}

We would like to thank all the heads and staff of community health centers in Padang City, especially patients with diabetes mellitus, then also the director of the Padang Health Polytechnic, especially the applied health promotion undergraduate program who have fully supported the implementation of this first stage of research

\section{REFERENCES}

[1] S. Basu, P. Yoffe, N. Hills, and R. H. Lustig, "The Relationship of Sugar to Population-Level Diabetes Prevalence : An Econometric Analysis of Repeated Cross- Sectional Data," PLoS One, vol. 8, no. 2, 2013.

[2] M. Baxter et al., "Estimating the impact of better management of glycaemic control in adults with Type 1 and Type 2 diabetes on the number of clinical complications and the associated financial benefit," Diabetic Medicine: A Journal of the British Diabetic Association, vol. 33, no. 11, pp. 1575-1581, 2016.

[3] P. Saeedi, et al., "Global and regional diabetes prevalence estimates for 2019 and projections for 2030 and 2045 : Results from the International Diabetes Federation Diabetes Atlas, 9th edition," Diabetes Research and Clinical Practice, vol. 157, p. 107843, 2019. 
[4] Center for Public Communication Secretariat General of the Ministry of Health of the Republic of Indonesia, "Diabetes mellitus is the number six cause of death in the world; The Ministry of Health offers smart solutions through guidance posts," Ministry of Health of the Republic of Indonesia, 2016. [Online]. Available: www.depkes.go.id.

[5] K. Ogurtsova, J. D. Rocha, Y. Huang, U. Linnenkamp, and L. Guariguata, "IDF Diabetes Atlas : Global estimates for the prevalence of diabetes for 2015 and 2040," Diabetes Research and Clinical Practice, vol. 128, pp. 40-50, 2017.

[6] World Health Organization, "Diabetes facts and figures/Diabetes fakta dan angka," World journal of diabetes, 2016. [Online]. Available: http://www.searo.who.int/indonesia/topics/8-whd2016-diabetes-facts-and-numbersindonesian.pdf.

[7] Kementerian Kesehatan RI, "Riskesdas/Basic health research,” Jakarta, 2018.

[8] BPSDM Kes., "Opportunities and Challenges of IAKMI in the Healthy Living Community Movement/Peluang Dan Tantangan IAKMI Pada Gerakan Masyarakat Hidup Sehat," Badan Pengembangan Dan Pemberdayaan Sdm Kesehatan Kementerian Kesehatan RI, Jakarta, pp. 4-10, 2017.

[9] Dinas Kesehatan Kota Padang, “2018 Annual Report 2019 Edition/Laporan Tahunan 2018 Edisi 2019,” Padang, 2019.

[10] K. P. N. Haida and I. M. Atoillah, "The relationship between the four pillars of type 2 DM control with blood sugar levels/Hubungan empat pilar pengendalian DM tipe 2 dengan rerata kadar gula darah," Jurnal Berkala Epidemiologi, vol. 1, no. 2, pp. 234-243, 2011.

[11] D. H. Iunes, C. B. J. Rocha, N. C. S. Borges, C. O. Marcon, V. M. Pereira, and L. C. Carvalho, "Self-care associated with home exercises in patients with type 2 diabetes mellitus," PLoS One, vol. 9, no. 12, 2014.

[12] H. Holman and K. Lorig, "Patient Self-Management: A Key to Effectiveness and Efficiency in Care of Chronic Disease," Public Health Reports, vol. 119, no. 3, pp. 239-243, 2004.

[13] C. H. Yu, et al., "A web-based intervention to support self-management of patients with type 2 diabetes mellitus: effect on self-efficacy, self-care and diabetes distress," BMC Medical Informatics and Decision Making, vol. 14, no. 1 , p. $117,2014$.

[14] M. Huang, R. Zhao, S. Li, and X. Jiang, "Self-management behavior in patients with type 2 diabetes: a crosssectional survey in western urban China," PLoS One, vol. 9, no. 4, 2014.

[15] J. Tuomilehto, "Type 2 diabetes is a preventable disease-lifestyle is the key," Journal of Medical Sciences, vol. 3, no. 2, pp. 82-86, 2010.

[16] Rahmawati, T. Tahlil, and Syahrul, "The effect of diabetes self-management education program on selfmanagement in patients with type 2 diabetes mellitus/Pengaruh program diabetes self-management education terhadap manajemen diri pada penderita diabetes mellitus tipe 2," Jurnal Ilmu Keperawatan, vol. 4, no. 1, pp. 4658,2016

[17] S. Norris, M. M. Engelgau, and V. Narayan, "Effectiveness of self-management training in type 2 diabetes a systematic review of randomized controlled trials," Diabetes Care, vol. 24, no. 3, pp. 561-567, 2001.

[18] M. A. F. Osman, E. T. Ahmed, and H. A.-T. S. Ahmed, "Effects of health education of diabetic patient's knowledge at Diabetic Health Centers, Khartoum State, Sudan: 2007-2010,” Global Journal of Health Science, vol. 6, no. 2, pp. 221-226, 2014.

[19] J. J. Gagliardino, J. Chantelot, C. Domenger, G. Kaddaha, J. C. Mbanya, and M. Shestakova, "Impact of diabetes education and self-management on the quality of care for people with type 1 diabetes mellitus in the Middle East (The International Diabetes Mellitus Practices Study, IDMPS)," Diabetes Research and Clinical Practice, vol. 147, pp. 29-36, 2018.

[20] BPJS, "PROLANIS practical guide (Chronic disease management program)," Jakarta: Health BPJS, 2014.

[21] R. Sidiq, J. Amos, and F. Hanum, "Self-management ability mediates the relationship of diabetes mellitus patients' activeness in prolanis with their quality of life," Diabetes Management, vol. 8, no. 6, pp. 147-153, 2018.

[22] D. J. Toobert, S. E. Hampson, and R. E. Glasgow, "The summary of diabetes self-care," Epidemiology/Health Services/Psychosocial Research, vol. 23, no. 7, pp. 943-950, 2000.

[23] Syatriani, S., Purnamawati, Y., "The Relationship of Compliance to Follow Prolanis with the Stability of Blood Sugar Levels of Patients with Type 2 Diabetes Mellitus at the Lumpue Health Center in Pare-Pare City," IAKMI Public Heal. J. Indonesia,.vol.1, no. 1, pp. 21-26, 2020.

[24] R. K. Dewi, Y. A. Romadhon, and A. Candrasari, "Relationship between blood glucose patients with diabetes mellitus type 2 and quality of life among PROLANIS Health Insurance participants at Surakarta," Thesis, Universitas Muhammadiyah Surakarta, 2014.

[25] M. S. D. Souza, R. Venkatesaperumal, S. D. Ruppert, S. N. Karkada, and D. Jacob, "Health related quality of life among omani men and women with type 2 diabetes," Journal of Diabetes Research, vol. 2016, 2016.

[26] S. Ventegodt, J. Merrick, and N. J. Andersen, "Quality of Life Theory I. The IQOL Theory: An Integrative Theory of the Global Quality of Life Concept," The Scientific World Journal, vol. 3, pp. 1030-1040, 2003.

[27] H. Habibzadeh, A. Sofiani, L. Alilu, and M. Gillespie, "The effect of group discussion-based education on selfmanagement of adults with type 2 diabetes mellitus compared with usual care: a randomized control trial," Oman Medical Journal, vol. 32, no. 6, pp. 499-506, 2017.

[28] W. M. Ong, siew siang Chua, and C. Jenn, "Barriers and facilitators to self-monitoring of blood glucose in people with type 2 diabetes using insulin: a qualitative study," Patient Preference and Adherence, vol. 8, pp. 237-246, 2014.

[29] X. Lu, Beng, and R. Zhang, "Impact of physician-patient communication in online health communities on patient compliance: cross-sectional questionnaire study," Journal of Medical Internet Research, vol. 21, no. 5, 2019. 
[30] S. R. Patton, "Adherence to glycemic monitoring in diabetes," Journal of Diabetes Science and Technology, vol. 9, no. 3, pp. 668-675, 2015.

[31] T. A. Miller, "Importance of family/social support and impact on adherence to diabetic therapy," Diabetes, Metabolic Syndrome and Obesity: Targets and Therapy, vol. 6, pp. 421-426, 2013.

[32] A. A. Baig, A. Benitez, M. T. Quinn, and D. L. Burnet, "Family interventions to improve diabetes outcomes for adults," Annals of the New York Academy of Sciences, vol. 1353, no. 1, pp. 89-112, 2016.

[33] F. O. MakkiAwouda, T. A. Elmukashfi, and S. A. H. Al-Tom, "Self-management education for adults with type 2 diabetes a meta-analysis of the effect on glycemic control," Glob. J. Health Sci., vol. 25, no. 7, 2010.

[34] Z. Ahmed and F. Yeasmeen, "Active family participation in diabetes self-care: a commentary," Diabetes Management, vol. 6, no. 5, pp. 104-107, 2016.

[35] M. Coyle, K. Francis, and Y. Chapman, "Self-management activities in diabetes care: A systematic review selfmanagement activities in diabetes care: a systematic review," Australian Health Review, vol. 37, no. 4, pp. 513-522, 2013.

[36] S. R. Colberg, et al., "Physical activity/exercise and diabetes: A position statement of the american diabetes association," Diabetes Care, vol. 39, no. 11, pp. 2065-2079, 2016.

[37] S. Chiang, M. M. Heitkemper, Y. Hung, W. Tzeng, M. Lee, and C. Lin, "Effects of a 12-week moderate-intensity exercise training on blood glucose response in patients with type 2 diabetes," Medicine, vol. 98, no. 36, 2019.

[38] M. Abebaw, A. Messele, M. Hailu, and F. Zewdu, "Adherence and associated factors towards ant diabetic medication among type 2 diabetic patients on follow-up at University of Gondar Hospital, Northwest Ethiopia," Advances in Nursing, vol. 2016, 2016.

[39] J. Bagonza, E. Rutebemberwa, and W. Bazeyo, "Adherence to anti diabetic medication among patients with diabetes in eastern Uganda ; a cross sectional study," BMC Health Services Research, vol. 15, pp. 168-174, 2015.

[40] G. Mutashambara et al., "Ant diabetic medication adherence and associated factors among patients in Botswana; implications for the future," Alexandria Journal of Medicine, vol. 54, no. 2, pp. 103-109, 2017.

[41] J. Kreutziger, et al., "Association between blood glucose and cardiac rhythms during pre-hospital care of trauma patients-a retrospective analysis," Scandinavian Journal of Trauma, Resuscitation and Emergency Medicine, vol. 26 , no. 1 , pp. 58-68, 2018.

[42] D. A. Mcallister, et al., "Stress hyperglycaemia in hospitalised patients and their 3-year risk of diabetes: A Scottish retrospective cohort study," PLoS Medicine, vol. 11, no. 8, 2014.

[43] B. Murti and D. Indarto, "Path Analysis on the Effects of Bio-psychosocial Factors and Calorie Intake in Blood Glucose Control in Patients with Type 2 Diabetes Mellitus," Indonesian Journal of Medicine, vol. 1, no. 2, pp. 9099, 2016.

[44] A. Mitra, "Diabetes and Stress: A Review Diabetes and Stress: A Review," Studies on Ethno-Medicine, vol. 2282657, no. 2, pp. 131-135, 2008

[45] D. Ayu, K. Wardani, and R. Cilmiaty, "Stress, Nutritional Status and Blood Glucose Levels among Patients with Diabetes Mellitus Type 2," International Journal of Public Health Science (IJPHS), vol. 7, no. 4, pp. 283-288, 2018.

[46] F. Z. Alavijeh, M. Araban, H. R. Koohestani, and M. Karimy, "The effectiveness of stress management training on blood glucose control in patients with type 2 diabetes," Diabetology and Metabolic Syndrome, vol. 10, no. 39, pp. 1-9, 2018.

Int. J. Public Health Sci. Vol. 10, No. 1, March 2021: $33-40$ 